\title{
IMPACTS OF AN EXOTIC DISEASE AND VEGETATION CHANGE ON FOLIAR CALCIUM CYCLING IN APPALACHIAN FORESTS
}

\author{
Michael A. Jenkins, ${ }^{1,4}$ Shibu Jose, ${ }^{2}$ and Peter S. White ${ }^{3}$ \\ ${ }^{1}$ National Park Service, Great Smoky Mountains National Park, Twin Creeks Natural Resources Center, \\ 1314 Cherokee Orchard Road, Gatlinburg, Tennessee 37738 USA \\ ${ }^{2}$ School of Forest Resources and Conservation, University of Florida, Box 110410, Gainesville, Florida 32611 USA \\ ${ }^{3}$ Department of Biology-Campus Box 3280, University of North Carolina at Chapel Hill, Chapel Hill, \\ North Carolina 27599-3280 USA
}

\begin{abstract}
Because of the high calcium content of its foliage, Cornus florida (flowering dogwood) has been described as a calcium "pump" that draws calcium from deeper mineral soil and enriches surface soil horizons. However, over the last two decades an exotic fungal disease (dogwood anthracnose, Discula destructiva) has decimated populations of this oncecommon understory species. Its loss, combined with forest stand development, could alter intra-stand calcium cycling. We used data from long-term vegetation monitoring plots to examine the ecological role of $C$. florida in calcium cycling and to identify changes in annual foliar calcium cycling over a 20-year period between two sampling intervals, 1977-1979 (preanthracnose) and 1995-2000 (post-anthracnose). Published equations were used to estimate foliar biomass per species for five forest types: alluvial, typic cove, acid cove, oak-hickory, and oak-pine. Calcium concentrations derived from foliage samples were used to estimate annual foliar calcium production per species for understory woody stems $(<20 \mathrm{~cm} \mathrm{dbh})$ and total foliar calcium production for overstory stems $(\geq 20 \mathrm{~cm}$ dbh). At a given level of soil calcium availability, C. florida foliage contained greater concentrations of calcium than three other dominant understory species (Tsuga canadensis, Acer rubrum, and Rhododendron maximum). Between 1977-1979 and 1995-2000, the annual calcium contributions of understory woody vegetation declined across all forest types, ranging from $26 \%$ in oak-pine stands to $49 \%$ in acid coves. Loss of $C$. florida was responsible for only $13 \%$ of this decline in oak-pine stands, but accounted for $96 \%$ of the decline in typic coves. In oak-hickory and oak-pine stands, we observed large increases in the foliar biomass of $T$. canadensis, a species whose calcium-poor foliage increases soil acidity. Increases in overstory foliar biomass and calcium offset understory losses in three forest types (alluvial, typic coves, and oak-pine) but not in oakhickory and acid cove stands. Overall, calcium cycling in oak-hickory stands was more negatively affected by the loss of $C$. florida than the other forest types. Oak-hickory forests comprise over a third of the total forest cover in the eastern United States, and decreases in annual calcium cycling could have cascading effects on forest biota.
\end{abstract}

Key words: calcium cycling; Cornus florida; dogwood anthracnose; exotic disease; forest stand development; long-term monitoring; soil calcium availability; southern Appalachian Mountains; temperate forests; tree mortality; Tsuga canadensis; understory vegetation.

\section{INTRODUCTION}

Calcium (Ca) serves many functions in regulating physiological and structural processes of plants (Jones 1998, McLaughlin and Wimmer 1999, Mengel et al. 2001). Despite its important role in plant metabolism and growth, Ca mobility is low and its uptake and distribution rate is a limiting factor for many key plant functions (Jones 1998, McLaughlin and Wimmer 1999). For these reasons, McLaughlin and Wimmer (1999) hypothesized that $\mathrm{Ca}$ supply exerts considerable control on both the structure and function of forest ecosystems.

Over the past two decades numerous studies have suggested that human activities are depleting ecosystem

Manuscript received 19 June 2006; revised 16 October 2006; accepted 18 October 2006. Corresponding Editor: J. Gulledge.

${ }^{4}$ E-mail: mike_jenkins@nps.gov
$\mathrm{Ca}$ across a broad range of forests in eastern North America (Federer et al. 1989, Cronan and Schofield 1990, Johnson and Lindberg 1992, Huntington 2000, Huntington et al. 2000) and Europe (Matzner and Murach 1995, Jönsson et al. 2003). Most studies have identified atmospheric deposition of sulfur and nitrogen oxides as a cause of soil acidification, resulting in aluminum mobilization and cation leaching (Cronan and Schofield 1990, Likens et al. 1996, Lawrence et al. 1999, Driscoll et al. 2001). In addition, reduced atmospheric deposition of Ca (Johnson et al. 1994) and uptake of Ca into woody biomass (Johnson et al. 1988, Johnson and Todd 1990) have been implicated in losses of $\mathrm{Ca}$ within forest ecosystems.

Within forest stands, Ca loss occurs in forest-floor organic horizons as a result of aluminum migrating from deeper soil horizons and displacing $\mathrm{Ca}$ (Lawrence et al. 
1995). Because of their high nutrient content compared to mineral soil, organic horizons are the primary rooting layer in forests (Lawrence et al. 1995) and contain the majority of soil fauna (Pritchett and Fisher 1987). Calcium losses in this layer have had serious impacts on other organisms. For example, on low-nutrient soils in the Netherlands, loss of snail shells linked to acid deposition limited the reproductive success of the Great Tit (Parus major; Graveland 1996). In the central Appalachian Mountains, land snail density and species richness were positively correlated with $\mathrm{Ca}$ availability (Hotopp 2002), and a similar impact on other passerine birds may be occurring.

Woody-species composition strongly influences soil chemistry, including exchangeable aluminum concentration and Ca availability (Blair 1988, Finzi et al. 1998, Dijkstra and Smits 2002). Soils beneath Acer saccharum trees have greater $\mathrm{Ca}$ availability (Dijkstra and Smits 2002) and lower levels of exchangeable aluminum (Finzi et al. 1998) than soils beneath Tsuga canadensis trees. Thomas (1969) found significantly greater exchangeable Ca under Cornus florida trees than under Pinus taeda. Because of the high Ca content and rapid decomposition of its foliage (Thomas 1969, Blair 1988), numerous authors have suggested that $C$. florida, one of the most common understory trees in eastern North America, may have an important ecological role in the $\mathrm{Ca}$ economy of forest stands (Thomas 1969, McLemore 1990, Hiers and Evans 1997, Jenkins and White 2002). As with most woody plants, Ca concentrations increase in $C$. florida foliage throughout the growing season, and no net resorption of $\mathrm{Ca}$ prior to leaf abscission has been observed (Kost and Boerner 1985, Potter et al. 1987). While numerous studies have shown that overstory vegetation heavily dominates total stand biomass (Crow 1978, Rutkowski and Stottlemyer 1993, Son et al. 2004), the relative contributions of overstory and understory woody vegetation to annual foliar biomass and $\mathrm{Ca}$ cycling have received limited attention.

Cornus florida is currently threatened across much of its range by Discula destructiva Redlin, a destructive fungus that causes dogwood anthracnose (Daughtrey and Hibben 1994, Holzmueller et al. 2006; see Plate 1). Genetic testing suggests that D. destructiva was introduced recently, possibly from Asia (Britton 1994). Mortality of $C$. florida has been severe over the past two decades throughout its range. In Franklin County, Tennessee (USA) Hiers and Evans (1997) observed a $98 \%$ decrease in C. florida density within a cove forest between 1983 and 1995. In western North Carolina (USA) Wyckoff and Clark (2002) observed a 15\% annual mortality rate for C. florida between 1991 and 1998. In Great Smoky Mountains National Park (GSMNP) between the late 1970s and 2000, decreases in the density of $C$. florida ranged from $69 \%$ in oak-pine stands to $>90 \%$ in cove forests (Jenkins and White 2002). Over this same period in GSMNP, the understory importance of $T$. canadensis has more than doubled across forest types in response to the loss of $C$. florida and over 60 years of fire suppression (Jenkins and White 2002). Based on these changes, we hypothesized that the rapid loss of a "calcium-pumping" species ( $C$. florida) combined with a drastic increase in a species with low levels of foliar $\mathrm{Ca}$ ( $T$. canadensis), has altered $\mathrm{Ca}$ cycling and availability in the forest floor and surface soil horizons of these forests, possibly impacting a chain of associated flora and fauna. Further, we hypothesized that these impacts are more pronounced on sites with low levels of available $\mathrm{Ca}$.

In this paper, we use data from a network of permanent vegetation plots in GSMNP to examine how the loss of $C$. florida trees and other changes in forest composition and structure have affected the annual cycling of $\mathrm{Ca}$ to the forest floor. More specifically, we address the following questions: (1) How does the Ca concentration of different understory woody species vary? (2) Does C. florida concentrate more $\mathrm{Ca}$ into its foliage than other dominant understory species on sites with low Ca availability? (3) Based upon calculated foliar biomass and $\mathrm{Ca}$ content, how did the amount of Ca returned to the forest floor annually by $C$. florida and other understory woody species change over a 20-year period (between 1977-1979 and 1995-2000) following anthracnose infection? (4) Based upon calculated foliar biomass and $\mathrm{Ca}$ content, how did the relative contributions of overstory and understory woody vegetation to foliage biomass and annual $\mathrm{Ca}$ cycling change over a 20-year period following anthracnose infection?

\section{Methods \\ Study site}

Because of its biotic diversity, large size $(>200000$ ha), and protected status, Great Smoky Mountains National Park (GSMNP), USA, is internationally renowned as a center of biological diversity. Complex ecological gradients combine to create a diverse mosaic of biological communities. Elevations in the Park range from $267 \mathrm{~m}$ to $2025 \mathrm{~m}$ and the rugged topography includes rocky summits, incised drainages, talus slopes, and level valleys. Annual rainfall varies from $140 \mathrm{~cm}$ at low elevations to $>200 \mathrm{~cm}$ on some high peaks. Seventynine unique vegetation associations comprised of nearly 1600 species of vascular plants have been identified within GSMNP (White et al. 2003, NPSpecies 2006). Because over $20 \%$ of the Park was never cleared of timber, GSMNP also contains one of the largest tracts of primary forest in eastern North America (Pyle 1988).

Between 1977 and 1979, 287 permanent 0.1-ha $(50 \times$ $20 \mathrm{~m}$ ) vegetation plots were established in the western end of GSMNP (White and Busing 1993). Watersheds were divided into sample sites based upon elevation, slope position, and aspect, and plots were randomly located within each sample site. These plots cover a broad range of site conditions and disturbance histories and include areas of mature forest, abandoned agricul- 

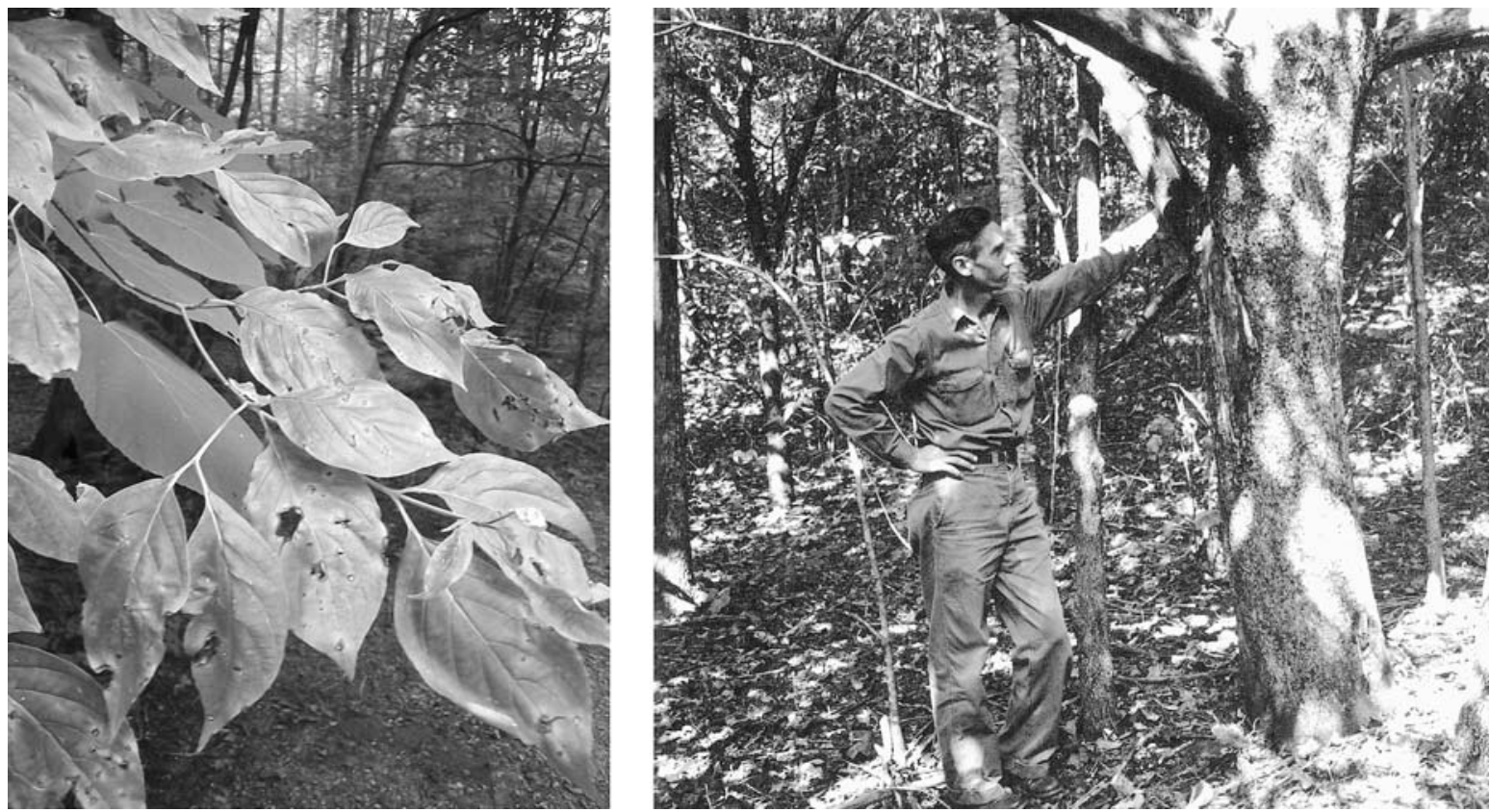

Plate 1. (Left) Flowering dogwood (Cornus florida) foliage during the early stage of infection with dogwood anthracnose (Discula destructiva). The edges of the leaves show the first symptoms of the disease, developing spots that extend down the leaf margins as the disease progresses. The fungus eventually reaches the bole of the tree where cankers develop, girdling and killing the tree. Infected trees growing in shaded conditions may die within 1-3 years of first infection; saplings may die in the same year they are infected. Photo credit: National Park Service. (Right) Photographed in 1959, this C. florida tree was thought to be the largest ever documented in GSMNP. Prior to anthracnose, $C$. florida often dominated the understory of stands that regenerated after logging and agricultural use. Photo credit: National Park Service.

tural land, limestone substrates, and past burning. For this study, we used data from 84 plots that contained Cornus florida and were resampled as part of GSMNP's long-term monitoring program and other research projects. Plot data were used to classify plots into five broad forest types: acid cove, typic cove, alluvial, oakhickory, and oak-pine (Jenkins and White 2002). Recent evaluation of data from plots that did not contain dogwood in 1977-1979 revealed that there has been little or no invasion of $C$. florida into new areas.

Acid cove forests were on gentle to moderately steep slopes and flats between 430 and $860 \mathrm{~m}$ elevation. They were often located near streams within concave and vshaped drainages. Typic cove forests were in moreprotected topographic positions on gentle to moderate slopes with northerly aspects and elevations of 410-890 $\mathrm{m}$. Alluvial forests were found on flats along mediumsized perennial streams between 330 and $640 \mathrm{~m}$ elevation. Soils underlying this forest type were relatively deep and loamy with large rocks. Most alluvial forest stands were formerly cleared for farming and settlement (Pyle 1988). Oak-hickory forests were generally on moderately steep northwest to south facing slopes ranging from 310 to $1020 \mathrm{~m}$ elevation and oak-pine forests were typically found on narrow ridges and knobs, middle and upper slopes, and other exposed sites. Aspects were generally southeast-northwest and slopes were gentle to moderately steep.

\section{Field sampling and laboratory analysis}

Data were collected from 84 permanent plots during two sampling intervals: 1977-1979 and 1995-2000. Plots were distributed across five forest types, alluvial forests $(n=11)$, typic cove forests $(n=16)$, acid cove forests $(n=$ 13), oak-hickory forests $(n=34)$ and oak-pine forests $(n$ $=10$ ). Within each $20 \times 50 \mathrm{~m}$ plot, the dbh (diameter at breast height $=1.37 \mathrm{~m}$ ) of all living stems $\geq 1 \mathrm{~cm}$ dbh was measured to the nearest $0.1 \mathrm{~cm}$ and recorded by species during the 1977-1979 survey, and for 76 of 84 plots remeasured during the 1995-2000 survey. For eight plots remeasured between 1995 and 2000, the density of all trees $<10 \mathrm{~cm}$ dbh were tallied by species into two dbh classes: $1-4.9 \mathrm{~cm}$ and $5.0-9.9 \mathrm{~cm}$. On these eight plots, the dbh of all trees $\geq 10 \mathrm{~cm}$ was measured and recorded by species.

Soil was sampled at 8 to 10 points throughout each plot and pooled into one sample per plot. At each sampling point within a plot, a hand spade was used to collect a sample of mineral soil from the A-horizon. Sampling depth was $\sim 10 \mathrm{~cm}$ on most plots. Samples were dried at $43^{\circ} \mathrm{C}$ for $8 \mathrm{~h}$, ground, and sifted through a 2-mm (number $10 \mathrm{mesh}$ ) sieve. Calcium and other cations were extracted from the soil by mixing $25 \mathrm{~mL}$ of $1 \mathrm{~mol} / \mathrm{L}$ neutral, ammonium acetate with $5 \mathrm{~g}$ of soil and shaking for $30 \mathrm{~min}$ (Suarez 1996). The filtered extract was analyzed with an inductively coupled plasma atomic emission spectrometer to determine the molar equiva- 

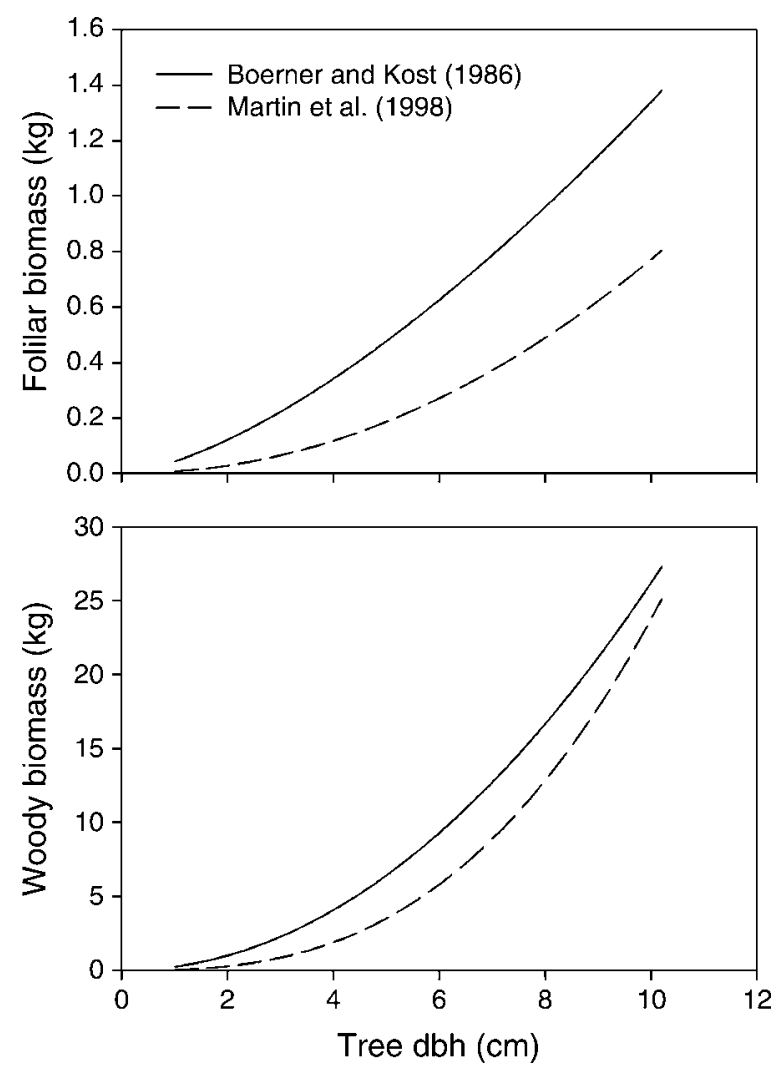

FIG. 1. Woody and foliar biomass curves for Cornus florida based upon equations developed by Beorner and Kost (1986) and Martin et al. (1998). Boerner and Kost (1986) equations were developed prior to the onset of dogwood anthracnose; Martin et al. (1998) equations were developed after impacts of anthracnose. The two sets of equations yield similar results for woody biomass, but Martin et al. (1998) yields much less foliar biomass for a given tree diameter.

lents of cations, including calcium (ICP-AES [inductively coupled plasma atomic emission spectrometer]; Soltanpour et al. 1996). This procedure saturates all soil exchange sites with ammonium ions (Sumner and Miller 1996). The ammonium ions are then dislodged with an acidic extractant and the cation exchange capacity (CEC) is calculated from the amount of ammonium thus displaced. The molar equivalents of individual cations (including calcium) are compared to the CEC and the base saturation percentage of each cation is determined. All soil analyses were performed by A\&L Analytical Laboratories, Memphis, Tennessee, USA.

Between late August and late October of both 2001 and 2003 we collected foliage from C. florida trees across the 84 plots we resampled. We also sampled the two or three most common understory woody species other than C. florida present in each plot. Typically, three individual trees of each species were sampled. However, no living $C$. florida trees remained on 16 plots, and on many plots there were fewer than three living $C$. florida trees. We used telescopic pole cutters to collect foliage at various positions in the crown to account for leaf development in response to varying light levels within the canopy. Specifically, the crown was divided into four quarters and leaves were collected from throughout each quarter when possible. A cord with a weight attached was thrown over higher branches and used to bend them down for sampling with the pole cutters. Generally, we were unable to collect foliage samples from overstory trees $(\geq 20 \mathrm{~cm} \mathrm{dbh})$. We combined all leaves from each tree into a single composite sample.

All samples were dried at $65^{\circ} \mathrm{C}$ for $72 \mathrm{~h}$ and fineground using a coffee grinder. All subsequent analyses were performed at the Analytical Research Laboratory of the University of Florida in Gainesville, Florida, USA. Samples were digested in a muffle furnace at $500^{\circ} \mathrm{C}$ for five hours before being dissolved in $6 \mathrm{~mol} / \mathrm{L}$ $\mathrm{HCl}$. Concentrations of $\mathrm{Ca}$ were determined on an inductively coupled plasma emission spectrometer (Perkin-Elmer Plasma 400ICP/AES; Perkin-Elmer, Norwalk, Connecticut, USA). All Ca concentrations are presented as milligrams per liter, $\mathrm{mg} / \mathrm{L}$.

\section{Foliar biomass}

Foliar biomass was calculated from dbh data using allometric equations (Appendix A). We did not calculate foliar biomass of Rhododendron maximum or Kalmia latifolia. All published biomass equations for these two species were based upon diameter at ground level, which is not measured as part of the GSMNP Vegetation Monitoring Protocols.

Cornus florida foliar biomass from the 1977-1979 sampling interval was estimated using a species-specific equation developed by Boerner and Kost (1986) prior to infection by dogwood anthracnose. For the 1995-2000 remeasurement, C. florida biomass was calculated with both the Boerner and Kost (1986) equation and a species-specific equation developed by Martin et al. (1998) in the southern Appalachians after dogwood anthracnose infection. While the equations of Boerner and Kost (1986) and Martin et al. (1998) show similar relationships between $\mathrm{dbh}$ and woody biomass, the output of the Martin et al. (1998) equation suggests that post-anthracnose stands are producing considerably less foliar biomass (Fig. 1). All foliar biomass values were converted to kilograms per hectare, $\mathrm{kg} / \mathrm{ha}$. Mean foliar biomass was calculated per species for each of the five forest types. Biomass was calculated separately for understory $(<20 \mathrm{~cm} \mathrm{dbh})$ and overstory $(\geq 20 \mathrm{~cm} \mathrm{dbh})$ vegetation. We used $20 \mathrm{~cm}$ dbh as the break between understory and overstory vegetation since it represented the maximum diameter for C. florida trees in both temporal sample intervals.

\section{Foliar calcium}

On each plot, foliar $\mathrm{Ca}$ concentrations (in milligrams per liter, $\mathrm{mg} / \mathrm{L}$ ) of all trees were averaged by species. To determine foliar Ca content of each species on a plot, we converted this average $\mathrm{Ca}$ concentration to a percentage 
TABLE 1. Tree sampling data for the 84 Great Smoky Mountains National Park (USA) resampled plots together with calcium concentration data for the various species, arranged in descending order of Ca concentration.

\begin{tabular}{|c|c|c|c|c|c|}
\hline \multirow[b]{2}{*}{ Species } & \multirow[b]{2}{*}{ Common name } & \multirow[b]{2}{*}{ No. sampled } & \multirow[b]{2}{*}{ Freq. $\dagger$} & \multicolumn{2}{|c|}{ Ca concentration $(\mathrm{mg} / \mathrm{L}) \ddagger$} \\
\hline & & & & Mean $\pm \mathrm{SE}$ & Range§ \\
\hline Tilia americana & American basswood & 2 & 13 & $22300 \pm 5610$ & $16690-27910$ \\
\hline Liriodendron tulipifera & tulip poplar & 7 & 34 & $17400 \pm 2692$ & $8120-27170$ \\
\hline Cornus florida & flowering dogwood & 120 & 68 & $17302 \pm 621$ & $3289-34460$ \\
\hline Fraxinus americana & white ash & 2 & 18 & $14870 \pm 4470$ & $10400-19340$ \\
\hline Acer saccharum & sugar maple & 15 & 25 & $13109 \pm 758$ & $8520-20560$ \\
\hline Halesia tetraptera & mountain silverbell & 41 & 47 & $13002 \pm 431$ & $8500-19280$ \\
\hline Carpinus caroliniana & American hornbeam & 6 & 14 & $12745 \pm 1477$ & $9490-19400$ \\
\hline Rhododendron maximum & rosebay rhododendron & 42 & 25 & $11705 \pm 362$ & $4551-16890$ \\
\hline Acer pensylvanicum & striped maple & 5 & 47 & $11014 \pm 2234$ & $7240-19610$ \\
\hline Carya spp. & hickory species & 3 & 49 & $9823 \pm 382$ & $9070-10300$ \\
\hline Betula lenta & black birch & 2 & 45 & $9575 \pm 2175$ & $7400-11750$ \\
\hline Magnolia spp. & magnolia species & 3 & 35 & $9560 \pm 1494$ & $7220-12340$ \\
\hline Kalmia latifolia & mountain laurel & 6 & 15 & $9205 \pm 357$ & $8240-10740$ \\
\hline Oxydendrum arboreum & sourwood & 9 & 54 & $9120 \pm 880$ & $6420-14960$ \\
\hline Lindera benzoin & spicebush & 3 & 6 & $8483 \pm 1651$ & $6430-11750$ \\
\hline Acer rubrum & red maple & 117 & 81 & $8268 \pm 238$ & $3677-17230$ \\
\hline Nyssa sylvatica & blackgum & 18 & 49 & $7862 \pm 362$ & $5440-10670$ \\
\hline Quercus spp. & oak species & 8 & 50 & $7341 \pm 677$ & $5730-11130$ \\
\hline Tsuga canadensis & eastern hemlock & 184 & 76 & $4632 \pm 114$ & $1826-10370$ \\
\hline Pinus spp. & pine species & 3 & 18 & $3601 \pm 780$ & $2041-4400$ \\
\hline Pinus strobus & white pine & 24 & 54 & $2920 \pm 158$ & $1951-4859$ \\
\hline
\end{tabular}

$\dagger$ Frequency $=$ number of plots (out of the total 84 plots) on which the species was found.

$\$$ Calcium concentration of foliage.

$\S$ Calcium concentration range by species across all plots sampled in 1995-2000.

and multiplied this value by the foliar biomass of each species. On plots with $100 \%$ C. florida mortality, Ca concentration values of the nearest plot of the same forest type were used to calculate foliar $\mathrm{Ca}$ content in 1977-1979. Since some of the species on our plots are conifers that do not drop all their leaves in a given year, we used leaf life-span values determined by Reich et al. (1999) to estimate the proportion of leaves dropped yearly for each species. These values were: 60 months for $T$. canadensis, 21 months for $P$. strobus and 33 months for yellow pine species (Pinus echinata, $P$. rigida, and $P$. virginiana). While we did not collect foliage samples from several less common species, on average our $\mathrm{Ca}$ concentration data allowed us to determine the $\mathrm{Ca}$ content of $>96 \%$ of the foliar biomass calculated for each plot. All Ca-content values were converted to kilograms per hectare, $\mathrm{kg} / \mathrm{ha}$. Mean values were calculated by species for understory vegetation $(<20$ $\mathrm{cm} \mathrm{dbh)} \mathrm{in} \mathrm{each} \mathrm{of} \mathrm{the} \mathrm{five} \mathrm{forest} \mathrm{types.}$

\section{Data analysis}

We used nonlinear regression to examine how the four dominant understory species (C. florida, Tsuga canadensis, Acer rubrum, and $R$. maximum) differ in their ability to concentrate foliar $\mathrm{Ca}$ on sites with low $\mathrm{Ca}$ availability. A nonlinear response curve was used to describe the relationships between foliar $\mathrm{Ca}$ content of each species (response variable) and percentage soil $\mathrm{Ca}$ saturation (predictor variable). We used percentage $\mathrm{Ca}$ cation saturation to represent available soil $\mathrm{Ca}$ since this measurement best represents the ease with which $\mathrm{Ca}$ may be displaced and taken up by plants (Brady 1990).
A nonlinear function was also used to examine the relationship between the foliar-to-soil $\mathrm{Ca}$ ratio and percentage soil $\mathrm{Ca}$ saturation. We estimated four parameters using the Marquardt-Levenberg nonlinear least squares algorithm. Plots of Studentized residuals vs. fitted values were used to assess the regression assumption of constant variance (Neter et al. 1996). Residual plots and standard techniques were used to screen for and evaluate the influence of potential outliers (Neter et al. 1996).

We used two-way repeated-measures ANOVA with sampling interval as the repeated factor and forest type as the nonrepeated factor to compare changes in individual understory species (including C. florida) biomass and $\mathrm{Ca}$ between sampling intervals and among forest types. Two-way repeated-measures ANOVA was also used to compare changes in total understory foliar biomass, total overstory foliar biomass, and total foliar biomass (understory and understory). Changes in total overstory Ca content were also compared using two-way repeated-measures ANOVA. $\log _{10^{-}}$and square-root transformations were used to homogenize variances and improve normality when necessary. Nontransformed summary data are presented for ease of interpretation.

\section{Results}

\section{Understory foliar calcium concentrations and uptake}

The foliar $\mathrm{Ca}$ concentration of understory woody vegetation varied greatly (Table 1). Concentrations ranged from $2920 \mathrm{mg} / \mathrm{L}$ for Pinus strobus to 22300 $\mathrm{mg} / \mathrm{L}$ for Tilia americana. Cornus florida and Liriodendron tulipifera foliage contained the next highest $\mathrm{Ca}$ 

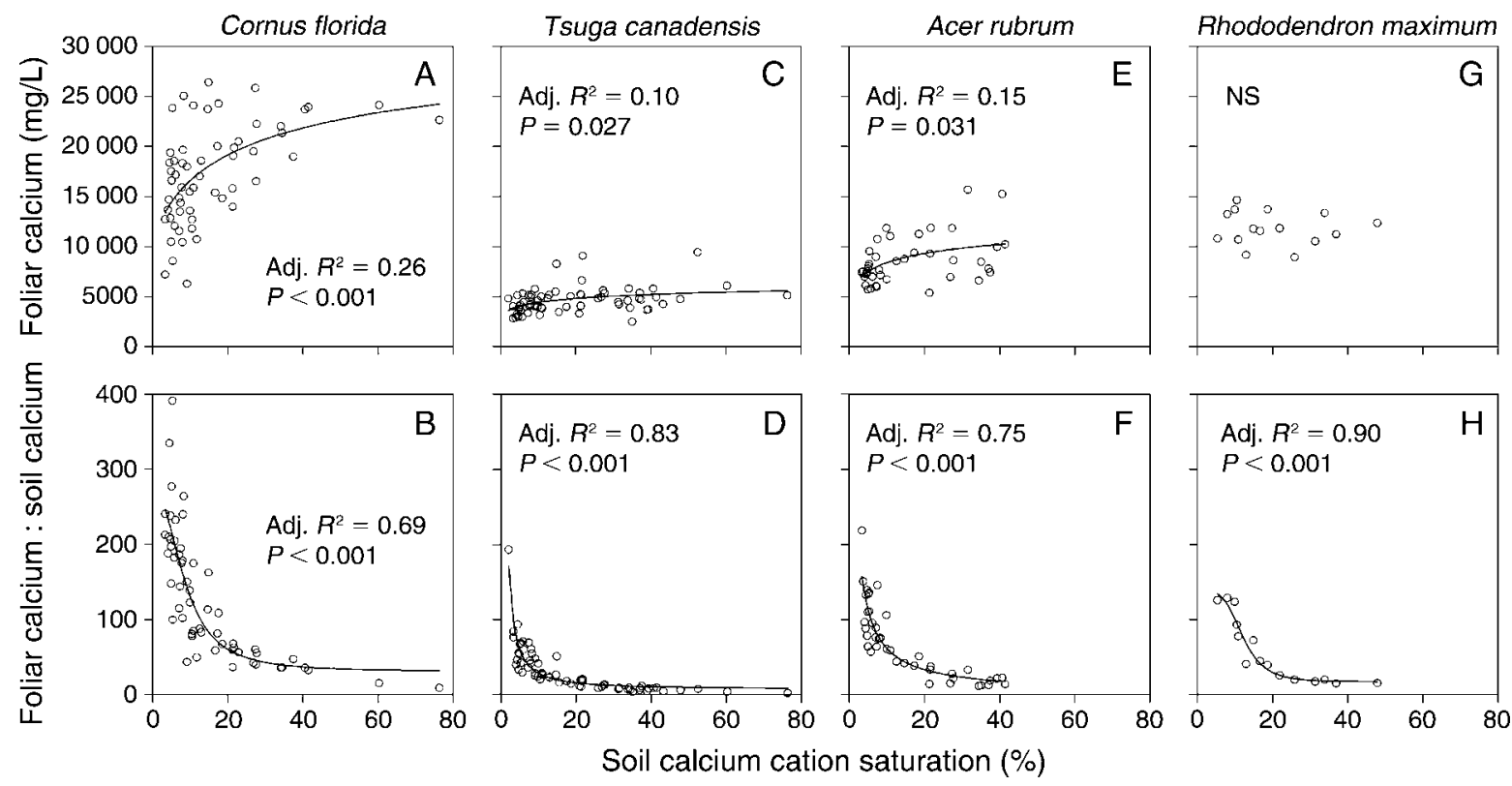

FIG. 2. Regression curves of foliar calcium and the ratio of foliar Ca to soil Ca vs. percentage soil Ca cation saturation for (A and B) Cornus florida, (C and D) Tsuga canadensis, (E and F) Acer rubrum, and ( $\mathrm{G}$ and $\mathrm{H})$ Rhododendron maximum. Curves were fit with the equation $f=(a-d) /\left[1+(x / c)^{b}\right]+d$.

concentrations (17302 and $17400 \mathrm{mg} / \mathrm{L}$, respectively). Among the dominant understory species (C. florida, Acer rubrum, Tsuga canadensis, and Rhododendron maximum), $C$. florida foliage contained the greatest concentration of $\mathrm{Ca}$. The $\mathrm{Ca}$ concentration of A. rubrum $(8268 \mathrm{mg} / \mathrm{L})$ was less than half that of C. florida, and that of $T$. canadensis was less than a third $(4632 \mathrm{mg} / \mathrm{L})$. Compared to A.rubrum and T. canadensis, $R$. maximum foliage was relatively rich in $\mathrm{Ca}(11705 \mathrm{~kg} / \mathrm{L})$. Cornus florida foliage exhibited the greatest range of $\mathrm{Ca}$ concentrations and highest single-plot value of any species $(34460 \mathrm{mg} / \mathrm{L})$.

Cornus florida displayed greater uptake of $\mathrm{Ca}$ into its foliage than did the other dominant understory species. Cornus florida foliage contained more $\mathrm{Ca}$ at a given level of soil Ca saturation than T. canadensis, A. rubrum, or R. maximum (Fig. 2). In addition, C. florida $\mathrm{Ca}$ concentration continued to increase with increasing soil $\mathrm{Ca}$ saturation after the curves of the other species leveled off. Cornus florida exhibited a much greater relative concentration of $\mathrm{Ca}$ in its foliage on low-Ca sites than did the other three dominant species, and C. florida also exhibited a much higher ratio of foliar $\mathrm{Ca}$ to soil $\mathrm{Ca}$ than other species on sites with low soil Ca saturation. The foliar $\mathrm{Ca}$ concentrations and foliar $\mathrm{Ca}$ to soil $\mathrm{Ca}$ ratios of the other threes species showed much less change with increasing soil $\mathrm{Ca}$ saturation compared to C. florida.

\section{Changes in understory foliar biomass and calcium content}

Both understory foliar biomass and foliar Ca contributions have declined within the five forest types (Appendix B). Typic coves exhibited the greatest decline in foliar biomass (from $683 \mathrm{~kg} / \mathrm{ha}$ in 1977-1979 to 365 $\mathrm{kg} / \mathrm{ha}$ in 1995-2000; 47\% decline) and alluvial and oakpine stands exhibited the least decline (from $1339 \mathrm{~kg} / \mathrm{ha}$ to $1039 \mathrm{~kg} / \mathrm{ha}$ and from $1492 \mathrm{~kg} / \mathrm{ha}$ to $1157 \mathrm{~kg} / \mathrm{ha}$, respectively; a $22 \%$ decline for both types). Oak-hickory and acid cove stands exhibited moderate decreases in foliar biomass. Foliar biomass declined $34 \%$ in oakhickory forests (from $1238 \mathrm{~kg} / \mathrm{ha}$ to $818 \mathrm{~kg} / \mathrm{ha}$ ) and $38 \%$ in acid coves (from $925 \mathrm{~kg} / \mathrm{ha}$ to $569 \mathrm{~kg} / \mathrm{ha}$ ). However, acid cove and oak-hickory stands exhibited the greatest decrease in total foliar $\mathrm{Ca}$ content. In acid cove understories, foliar $\mathrm{Ca}$ inputs declined from $8.16 \mathrm{~kg} / \mathrm{ha}$ to $4.16 \mathrm{~kg} / \mathrm{ha}$; a $49 \%$ decline. In oak-hickory stands, Ca inputs declined from $11.57 \mathrm{~kg} / \mathrm{ha}$ to $6.73 \mathrm{~kg} / \mathrm{ha}$; a $42 \%$ decline. Calcium input declines in the understories of the other three forest types ranged from $23 \%$ in typic coves (from $7.76 \mathrm{~kg} / \mathrm{ha}$ to $5.95 \mathrm{~kg} / \mathrm{ha}$ ) to $27 \%$ in alluvial stands $(11.14 \mathrm{~kg} / \mathrm{ha}$ to $8.08 \mathrm{~kg} / \mathrm{ha})$.

We observed a significant interaction $(P<0.001)$ between forest type and sampling interval for total understory foliar biomass, indicating differences in the decline among forest types. In 1977-1979 there were no significant differences in biomass among forest types. However, in 1995-2000 typic coves contained less foliar biomass than the other three forest types $(P<0.001$ for all types). In addition, oak-pine stands also contained greater foliar biomass than acid cove stands in 1995$2000(P<0.001)$. While two-way repeated-measures ANOVA revealed a significant interaction between forest type and sampling interval for total biomass (combined overstory and understory) post hoc tests showed no significant differences ( $P>0.1$ for all types). 

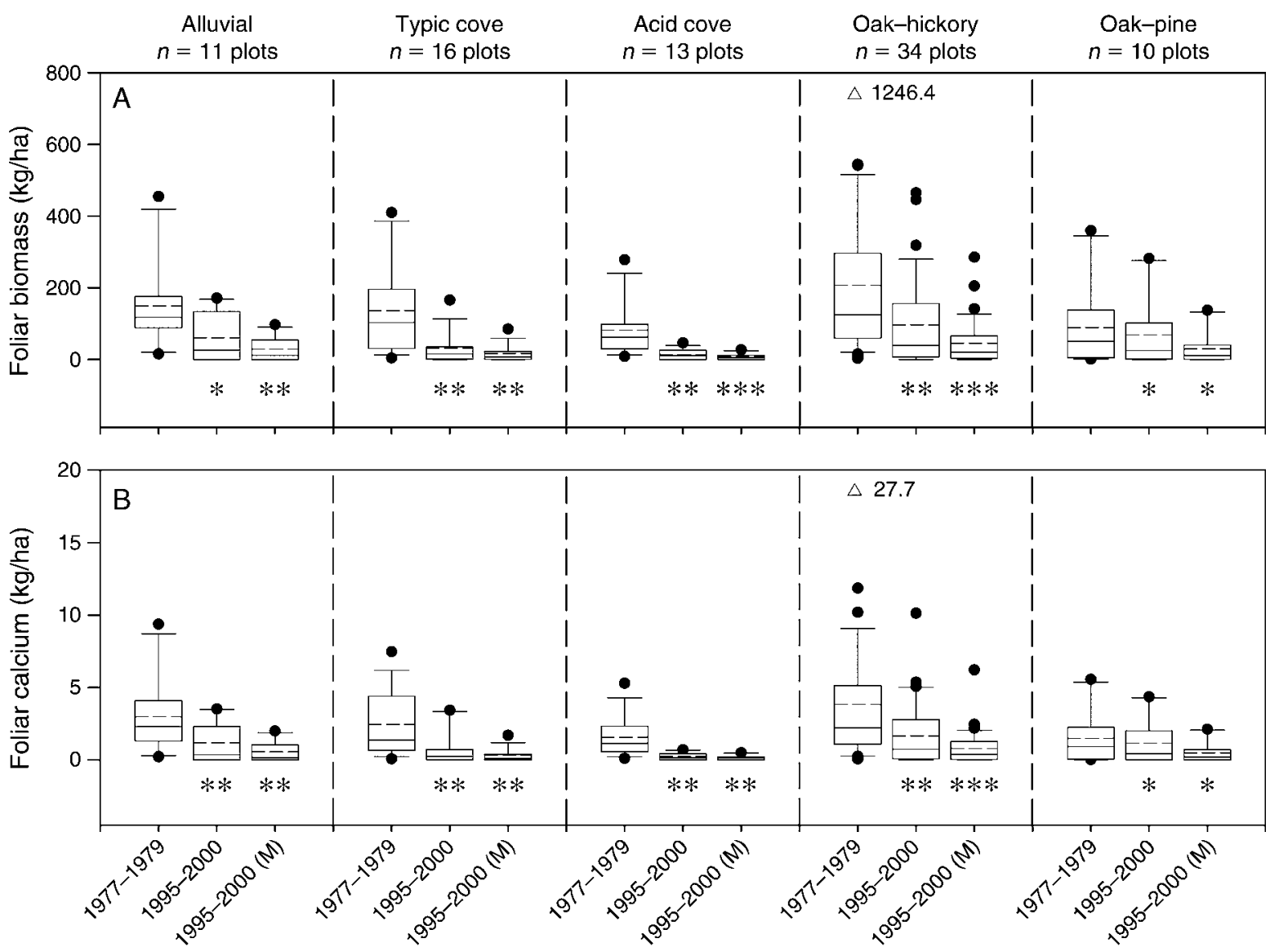

FIG. 3. Annual foliar (A) biomass and (B) calcium inputs from Cornus florida on five forest types. Values for the 1977-1979 and 1995-2000 sampling intervals were calculated using the foliar biomass equation developed by Boerner and Kost (1986). The equation developed by Martin et al. (1998) was also used to calculate values for the 1995-2000 sampling interval ["1995-2000 (M)"]. Plots show means (dashed horizontal lines), medians (solid horizontal lines), 25th and 75th percentiles (box ends), and 10th and 90th percentiles (whiskers). All outliers are also depicted $(\bullet)$. Values are provided for two outliers $(\triangle)$ in oak-hickory forests that were outside the range of the $y$-axis. Two-way repeated-measures ANOVA with Tukey's multiple-comparison tests were used to compare 1977-1979 means to 1995-2000 and 1995-2000 (M) means across all forest types: ${ }^{*} P<0.05,{ }^{* *} P<0.01,{ }^{* * *} P<0.001$.

\section{Changes in the contribution of $\mathrm{C}$. florida to foliar biomass and calcium cycling}

The loss of C. florida between 1977-1979 and 19952000 has resulted in a loss of $C$. florida foliar biomass and foliar Ca content within the five forest types (Fig. 3). Prior to the onset of dogwood anthracnose infection, mean C. florida foliar biomass ranged from $81 \mathrm{~kg} / \mathrm{ha}$ on acid cove plots to $207 \mathrm{~kg} /$ ha on oak-hickory plots. The decrease in biomass and Ca content was greatest in acid coves, where $C$. florida foliar biomass and Ca content declined by 84 and $85 \%$, respectively. However, $C$. florida foliar biomass and $\mathrm{Ca}$ content were greatest in oak-hickory stands, where mean foliar Ca contributions declined from $3.84 \mathrm{~kg} / \mathrm{ha}$ in $1977-1979$ to $1.66 \mathrm{~kg} / \mathrm{ha}$ in 1995-2000. Interestingly, foliar $\mathrm{Ca}$ contributions in 1977-1979 showed a large range on individual plots across forest types, varying from a low of $0.24 \mathrm{~kg} / \mathrm{ha}$ in acid cove stands to a maximum of $27.72 \mathrm{~kg} / \mathrm{ha}$ in oakhickory stands. Following the impacts of anthracnose, oak-hickory stands still contained the greatest $C$. florida foliar biomass and Ca content, although inputs declined by 53 and $57 \%$, respectively. Following anthracnose infection, the range of $\mathrm{Ca}$ inputs from $C$. florida on individual plots ranged from a low of $0 \mathrm{~kg} / \mathrm{ha}$ and to a maximum of $10.13 \mathrm{~kg} /$ ha in oak-hickory stands. Foliar $\mathrm{Ca}$ inputs after anthracnose infection, based upon the foliar biomass equation developed by Martin et al. (1998), were much lower than pre-anthracnose levels, with no forest type exceeding a mean input of $1 \mathrm{~kg} / \mathrm{ha}$. In addition, the maximum input on an individual plot was only $6.23 \mathrm{~kg} /$ ha in an oak-hickory stand.

Loss of $C$. florida accounted for much of the loss in understory $\mathrm{Ca}$ cycling across the five forest types (Appendix B). In typic cove stands, the loss of $C$. florida was responsible for $96 \%$ of the observed decrease in calcium inputs between 1977-1979 and 1995-2000. The loss of C. florida accounted for $59 \%$ of the observed loss in alluvial stands, $45 \%$ in oak-hickory stands, and $33 \%$ in typic cove stands. The loss of C. florida made 
relatively minor contribution $(13 \%)$ to the total loss of $\mathrm{Ca}$ in oak-pine stands.

We observed a significant interaction between forest type and sampling interval for $C$. florida foliar biomass, indicating differences in the decline among forest types. Results from Tukey pairwise multiple-comparison tests show no significant differences in foliar biomass for the first sampling interval (1977-1979; $P$ values ranged from 0.061 to 0.983 ). However, in 1995-2000 oak-hickory plots contained greater foliar biomass than did acid cove plots $(P=0.006)$. The interaction between forest type and sampling interval was insignificant for foliar $\mathrm{Ca}$ content $(P=0.212)$.

\section{Changes in the contributions of other understory species to foliar biomass and calcium content}

In addition to changes in understory foliar biomass and $\mathrm{Ca}$ content resulting from the loss of $C$. florida, we observed changes in the foliar biomass and $\mathrm{Ca}$ of other species across the five forest types (Appendix B). In alluvial understories, foliar biomass from Pinus spp. declined from $175 \mathrm{~kg} / \mathrm{ha}$ to $24 \mathrm{~kg} / \mathrm{ha}$ and foliar Ca content declined from $0.63 \mathrm{~kg} /$ ha to $0.09 \mathrm{~kg} / \mathrm{ha}(P<$ 0.05 and $P<0.001$, respectively). In addition, Ca inputs from $L$. tulipifera decreased from $1.80 \mathrm{~kg} / \mathrm{ha}$ to 1.17 $\mathrm{kg} /$ ha $(P<0.1)$, but inputs from $T$. canadensis increased slightly from $0.69 \mathrm{~kg} /$ ha to $0.83 \mathrm{~kg} / \mathrm{ha}(P<0.05)$. In typic coves, understory foliar biomass and $\mathrm{Ca}$ contributions from Halesia tetraptera declined $(P<0.05$ and $P<0.001$, respectively). Calcium contributions from understory $L$. tulipifera trees also declined in typic coves (from $0.94 \mathrm{~kg} /$ ha to $0.38 \mathrm{~kg} /$ ha; $P<0.01$ ). In acid coves, the foliar biomass and Ca contributions of Oxydendrum arboreum and Carya spp. declined. Oak-hickory stands exhibited declines in the foliar biomass and calcium contributions of A. rubrum, Carya spp., O. arboreum, and Quercus spp. The inputs of foliar $\mathrm{Ca}$ from $T$. canadensis increased in oak-hickory stands from 0.61 $\mathrm{kg} / \mathrm{ha}$ to $0.94 \mathrm{~kg} / \mathrm{ha}$. This increase only offset a small portion of the total Ca loss in this forest type $(4.84 \mathrm{~kg} / \mathrm{ha}$ between 1977-1979 and 1995-2000). In 1977-1979, Quercus spp. contributed more foliar biomass and Ca than any other species in oak-pine stands $(531 \mathrm{~kg} / \mathrm{ha}$ and $3.9 \mathrm{~kg} / \mathrm{ha}$, respectively). However, in 1995-2000 both foliar biomass (163 kg/ha) and Ca (1.24 kg/ha) contributions from Quercus spp. declined greatly $(69 \%$ and $68 \%$, respectively).

Two-way repeated-measures ANOVA revealed a significant interaction between sampling interval and forest type for foliar biomass of Quercus spp. However, post hoc tests revealed no changes in relative foliar biomass of Quercus spp. among forest types between sampling intervals. During both sampling intervals, oak-pine and oak-hickory stands contained greater Quercus spp. foliar biomass than the other forest types ( $P<0.05$ for all types). Analyses also revealed a significant interaction for $A$. pensylvanicum. In 19771979, the foliar biomass of $A$. pensylvanicum did not differ among forest types ( $P>0.05$ for all types). In 1999-2000, oak-hickory stands contained greater foliar biomass of this species than either alluvial or oak-pine stands ( $P=0.006$ and $P=0.040$, respectively).

Several individual species or species groups $(O$. arboreum, Carya spp., Pinus spp., and Quercus spp.) exhibited significant interactions between forest type and sampling interval for foliar Ca content. In 1977-1979, understory $O$. arboreum trees in typic cove stands contributed less $\mathrm{Ca}$ than in any other forest type $(P<$ 0.05 for all types). In 1995-2000, contributions of Ca from this species were significantly greater in alluvial stands than in typic coves $(P=0.006)$, but no other differences existed among forest types. In 1977-1979, Ca contributions from Carya spp. were greater in oakhickory stands than in any other forest type $(P<0.01$ for all types). In 1995-2000, the difference in Ca contributions was no longer significant between oakhickory stands and alluvial stands $(P=0.134)$. In $1977-$ 1979, alluvial and oak-pine stands received significantly greater $\mathrm{Ca}$ contributions from Pinus spp. than did the other forest types $(P<0.001$ for all types). However, in 1995-2000, alluvial stands no longer received greater contributions from this species group $(P>0.7$ for all types). In 1977-1979, oak-pine stands received significantly greater Ca contributions from Quercus spp. than typic cove, acid cove, alluvial, and oak-hickory stands ( $P<0.001$ for all types). In addition, oak-hickory stands received greater contributions than typic cove, acid cove, and alluvial stands ( $P<0.001$ for all types). In 1995-2000, oak-pine stand contributions were still significantly greater than the other four forest types $(P$ $<0.05$ for all types), but differences between oakhickory stands and the other forest types were no longer significant $(P>0.1$ for all types).

\section{Changes in relative contributions of understory and overstory vegetation}

Foliar biomass of the understory layer varied by forest type and generally decreased between the 19771979 and 1995-2000 sampling intervals (Fig. 4). In 1977-1979, the woody understories of oak-pine and alluvial forest stands contributed $44 \%$ and $49 \%$ of total foliar biomass, respectively. However, by 1995-2000, this contribution declined to $32 \%$ for both forest types. Understory vegetation contributed $33 \%$ of foliar biomass in oak-hickory stands in 1977-1979, but only $24 \%$ in 1995-2000. Typic and acid cove stands exhibited similar decreases in the percent of foliar biomass contributed by understory vegetation, a decrease from approximately $25 \%$ in both types to $15 \%$ and $18 \%$, respectively. Losses of understory foliar biomass were offset in alluvial and oak-pine stands by increases in overstory foliar biomass (Fig. 4). Overstory foliar biomass increased from $1721 \pm 318 \mathrm{~kg} / \mathrm{ha}$ to $2201 \pm$ $293 \mathrm{~kg} / \mathrm{ha}(28 \% ; P=0.007)$ in alluvial stands and from $1542 \pm 298 \mathrm{~kg} / \mathrm{ha}$ to $2460 \pm 397 \mathrm{~kg} / \mathrm{ha}(60 \% ; P=0.007)$ in oak-pine stands (all data: means $\pm \mathrm{SE}$ ). 


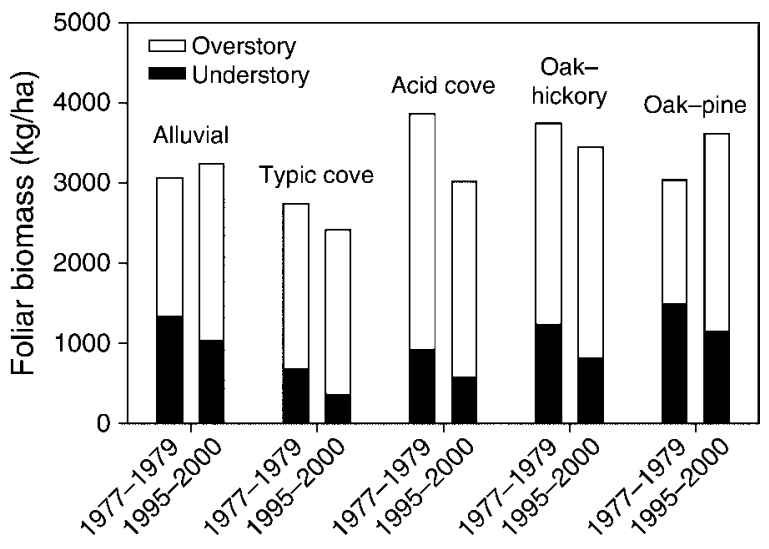

FIG. 4. Changes in the relative contribution of understory and overstory woody vegetation to foliar biomass of five forest types between 1977-1979 and 1995-2000.

While all forest types exhibited decreases in $\mathrm{Ca}$ contributed by understory vegetation, inputs from the overstory increased on four forest types (Fig. 5). Foliar $\mathrm{Ca}$ content in oak-pine stands increased from $8.8 \pm 1.5$ $\mathrm{kg} / \mathrm{ha}$ to $14.4 \pm 1.5 \mathrm{~kg} / \mathrm{ha}(P=0.004)$, a $64 \%$ increase. In alluvial stands, inputs of $\mathrm{Ca}$ from overstory foliage increased from $9.6 \pm 2.3$ to $13.2 \pm 2.4 \mathrm{~kg} / \mathrm{ha}(P=0.001)$, a $36 \%$ increase. Calcium inputs from overstory foliage increased less in typic cove and oak-hickory stands (17\% and $6 \%$, respectively). In typic coves, $\mathrm{Ca}$ inputs from overstory foliage increased from $24.8 \pm 4.1$ to $29.1 \pm 2.5$ $\mathrm{kg} / \mathrm{ha} \quad(P=0.041)$. In oak-hickory stands, inputs increased from $18.5 \pm 2.3$ to $19.6 \pm 1.2 \mathrm{~kg} / \mathrm{ha}(P=$ $0.033)$. Foliar $\mathrm{Ca}$ inputs from overstory vegetation did not change significantly in acid cove stands $(24.0 \pm 5.7$ $\mathrm{kg} / \mathrm{ha}$ to $20.0 \pm 2.3 \mathrm{~kg} / \mathrm{ha} ; P=0.469)$. Our analyses revealed no significant interactions between forest type and sampling interval for understory or overstory foliar $\mathrm{Ca}$ content.

\section{Discussion}

\section{Calcium uptake by $\mathrm{C}$. florida and other understory species}

In our study, Cornus florida concentrated more $\mathrm{Ca}$ in its foliage on low $\mathrm{Ca}$ sites than other common understory species (Tsuga canadensis, Acer rubrum, or Rhodendron maximum). The ratio of foliar to gross soil $\mathrm{Ca}$ was remarkably higher on sites with low levels of available Ca. Kost and Boerner (1985) observed that $C$. florida trees accumulated Ca most efficiently on the least fertile sites, producing 30-35\% more leaf mass per unit $\mathrm{Ca}$ in mixed oak vs. mixed mesophytic forests. In a comparative study of $A$. saccharum and $T$. canadensis, Dijkstra and Smits (2002) found that most Ca cycling occurs in surface soils, and a relatively small amount of Ca uptake from deep soil is able to sustain high amounts of available $\mathrm{Ca}$ in the surface soil.

Future stand development could further decrease available $\mathrm{Ca}$ in the forest floor and surface soils. Exchangeable $\mathrm{Ca}$ in the forest floor and surface soil horizons decreases through time, primarily due to high rates of $\mathrm{Ca}$ incorporation into the woody tissue of overstory trees (Johnson et al. 1988). Without C. florida serving as a "calcium pump" for the forest floor, the effects of Ca locked up for decades into woody tissue are augmented. In additions to its high rate of Ca uptake, $C$. florida litter decomposes more quickly than competing species. Blair (1988) found that C. florida litter decomposed more rapidly than both $A$. rubrum and Quercus prinus. Because of its higher initial $\mathrm{Ca}$ concentration, efficient production of foliar biomass, and rapid decomposition, $C$. florida provided sustained and regular inputs of $\mathrm{Ca}$ into the forest floor prior to anthracnose infection.

\section{Changes in the contribution of $\mathrm{C}$. florida to annual calcium cycling}

Our results show that the loss of $C$. florida trees that resulted from dogwood anthracnose has reduced the amount of calcium annually cycled through the leaf litter of understory vegetation. Much of this loss in alluvial, typic cove, and oak-pine stands may have been counterbalanced by increased contributions from overstory foliage (Fig. 5). However, acid cove and oakhickory stands, the two forest types that experienced the greatest loss in annual $\mathrm{Ca}$ contributed by understory foliage, exhibited slight (oak-hickory) or no (acid coves) increase in overstory foliar $\mathrm{Ca}$ inputs to compensate for understory losses.

The biological significance of net losses in annual $\mathrm{Ca}$ distributed to the forest floor is difficult to assess. Because we were unable to collect litter samples from overstory trees, direct comparisons between overstory and understory foliar $\mathrm{Ca}$ must be made with caution. Foliar $\mathrm{Ca}$ concentrations have been shown to vary within species as a result of age, height, crown class, and microenvironment (Van Den Driessche 1974). The concentrations of $\mathrm{Ca}$ in our study are similar to those determined by Day and Monk (1977) in a study conducted at Coweeta Hydrologic Laboratory (Otto,

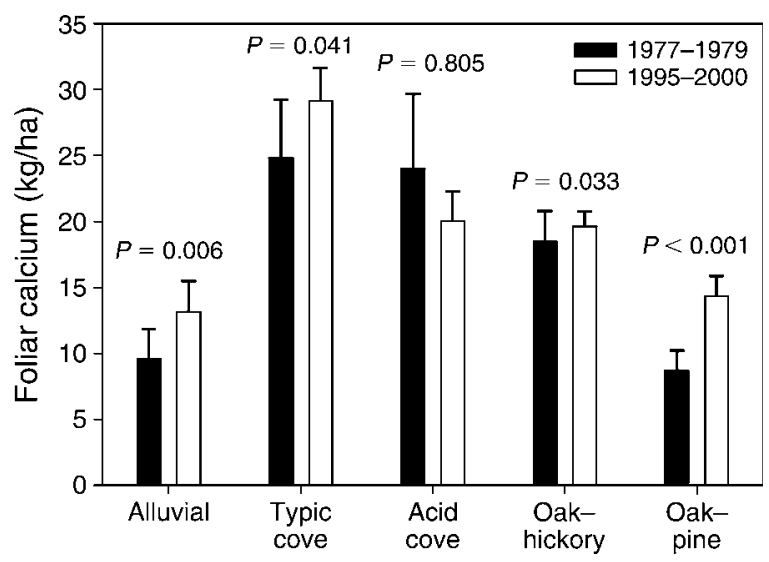

FIG. 5. Changes in foliar calcium of overstory vegetation from five forest types between 1977-1979 and 1995-2000. 
North Carolina, USA) that included both understory and overstory trees. In addition, the relative concentrations of foliar $\mathrm{Ca}$ across species is nearly identical between Day and Monk (1977) and our study. However, given the potential limitation of our $\mathrm{Ca}$ concentration data, we have only made temporal comparisons (19771979 vs. 1995-2000) of relative changes in overstory foliar $\mathrm{Ca}$ and do not present our results as a definitive quantification of overstory $\mathrm{Ca}$ contents of individual species.

The summed overstory and understory contribution prior to anthracnose from our study $(30 \mathrm{~kg} / \mathrm{ha})$ is similar to those reported for another oak-hickory forest in east Tennessee, USA (34 kg/ha; Johnson and Todd 1990), and a mixed-hardwood forest adjacent to Great Smoky Mountains National Park (GSMNP) (27 kg/ha; Gist and Crossley 1975) for the same period. If we assume that our total foliar $\mathrm{Ca}$ value is an acceptable approximation, then the oak-hickory stands we sampled have sustained a $12 \%$ decline in annual foliar $\mathrm{Ca}$ contributions. More striking, prior to anthracnose across the five forest types, we observed a wide range in the amount of foliar Ca contributed by $C$. florida in individual stands: from $0.2 \mathrm{~kg} / \mathrm{ha}$ to $27.7 \mathrm{~kg} / \mathrm{ha}$. This suggests that $C$. florida trees may have created "hot spots" of Ca within forest stands.

In a study conducted in the southern Appalachians (USA), Knoepp et al. (2005) found that the initial concentration of $\mathrm{Ca}$ in C. florida after leaf fall declined $18 \%$ between 1969-1970 and 1992-1993 sampling intervals. In addition to Ca, Knoepp et al. (2005) also observed overall declines in concentrations of phosphorus, magnesium, and potassium for C. florida, $Q$. prinus, Q. alba, A. rubrum, and Pinus strobus for the same time intervals. This suggests that the cation concentration of leaf litter in the southern Appalachians may have declined, regardless of species. Consequently, our estimates of foliar Ca contributions in 1977-1979 may underestimate actual values since we derived our Ca concentration data from samples gathered in 2001 and 2003.

\section{Contributions of other understory species to foliar biomass and annual calcium cycling}

Within our study area, the relative importance of $T$. canadensis in the understory increased over time in all forest types (Jenkins and White 2002). While the gross contribution of $T$. canadensis to annual foliar biomass and $\mathrm{Ca}$ increased in oak-hickory and oak-pine forests, its relative contributions increased for all forest types. Most striking was the increase in $T$. canadensis foliar biomass in oak-hickory stands, where the contribution from this species increased from $10 \%$ to $26 \%$ of total foliar biomass. In addition, the contribution of hardwood trees in oak-hickory stands to foliar biomass declined from $64 \%$ to $48 \%$ between sampling intervals. The forest floor and surface soil under canopies of $T$. canadensis have been shown to have lower $\mathrm{pH}$, reduced exchangeable $\mathrm{Ca}$ and $\mathrm{Mg}$, and greater exchangeable $\mathrm{Al}$ and $\mathrm{Fe}$ than that which occurs under hardwood canopies (Finzi et al. 1998). Because T. canadensis saplings grow more rapidly in low-calcium soils (Kobe 1996), the loss of $C$. florida from the forest understory may have contributed to the rapid increase in $T$. canadensis dominance. Tsuga canadensis is highly shade tolerant and the loss of $C$. florida and subsequent replacement by $T$. canadensis has accelerated succession in these stands. Further, increased soil acidity and reduced cation availability have been shown to increase the virulence of dogwood anthracnose (Britton et al. 1996; Holzmueller et al., in press). Consequently, increased soil acidification and cation leaching resulting from $T$. canadensis litter and atmospheric deposition may have accelerated foliage loss and mortality of $C$. florida trees due to anthracnose.

If understory $T$. canadensis trees are able to persist and reach the canopy, the amount of exchangeable $\mathrm{Ca}$ in the surface soil in these stands may be drastically reduced. A model derived by Dijkstra and Smits (2002) showed that on sites with high total mineral $\mathrm{Ca}$ concentrations, dominance by $T$. canadensis reduced exchangeable $\mathrm{Ca}$ in the surface soil by $\sim 75 \%$ in 150 years. However, with the recent onset of the exotic hemlock woolly adelgid (Adelges tsugae) in GSMNP, $T$. canadensis will likely experience heavy morality (Taylor 2002), further altering species composition and nutrient cycling within these stands.

Because of the lack of suitable biomass equations, we did not include foliar biomass or $\mathrm{Ca}$ contributions from R. maximum or Kalmia latifolia in this study. Kalmia latifolia was not a major understory species in the stands we sampled, but $R$. maximum was the second most dominant understory species in acid coves, second only to T. canadensis (Jenkins and White 2002). However, the importance of this species was unchanged between 1977-1979 and 1995-2000 (Jenkins and White 2002). Consequently, the contributions of $R$. maximum to foliar biomass and $\mathrm{Ca}$ cycling can likely be viewed as a constant input between sampling intervals. In addition, our results show that $R$. maximum foliage contains a relatively moderate concentration of $\mathrm{Ca}$ (11705 \pm 362 $\mathrm{mg} / \mathrm{L}$ ) compared to other species we sampled, and according to Reich et al. (1999) the life span of $R$. maximum leaves is 48 months, suggesting that it is less of a contributor to yearly foliar biomass cycling than most deciduous species.

\section{Relative contributions of understory and overstory vegetation}

The results of our study show that understory vegetation is a major contributor to total foliar biomass in some forest stands. In the 1970s, understory vegetation in GSMNP contributed up to $49 \%$ of total stand foliar biomass. In three 31-34 yr-old mixed-oak stands in Korea, Son et al. (2004) found that understory vegetation contributed only $3-13 \%$ of the stands total 
foliar biomass. However, these stands were still in the stem-exclusion stage of stand development (Oliver and Larson 1996) and other studies have shown that total foliage biomass increases with stand age (Long and Turner 1975, Santa Regina et al. 2001). Across all forest types in this study, foliar biomass contributed by understory vegetation decreased between sampling intervals. The plots we sampled in this study were in areas that were subjected to logging, broadcast burning, and livestock grazing prior to the creation of GSMNP (Pyle 1988). Due to ongoing stand development, canopies on these plots likely have become more closed since the 1970s, resulting in reduced understory density and biomass. The contribution of the overstory to foliar biomass and calcium content has increased as a result of crown expansion and canopy closure.

As stands reach the understory reinitiation stage of development, the woody understory will become more developed (Oliver and Larson 1996) and may make a larger contribution to total foliar biomass and $\mathrm{Ca}$ content. As canopy trees begin to decline and die, the contribution of the overstory to foliar biomass and calcium content may decrease. Because the woodyspecies compositions of the overstory and understory layers are often very different, the contribution of Ca per unit mass from the two layers may differ. For example, throughout much of the Midwestern United States the understories of oak stands are dominated by Acer saccharum (Pallardy et al. 1988, Jenkins and Parker 1998), a species whose litter is typically much richer in calcium than oaks (Table 1).

\section{Ecological impacts and management implications}

Our results suggest that oak-hickory forests are the most likely of the five forest types to have been affected by decreased cycling of Ca resulting from the loss of $C$. florida and the drastic increase in the understory importance of $T$. canadensis. This forest type experienced a $42 \%$ decline in the amount of $\mathrm{Ca}$ cycled by understory woody vegetation; a loss that was not completely offset by increased overstory contributions. In the eastern United States, oak-hickory forest comprises $34 \%$ of the total forest area $\left(53 \times 10^{6}\right.$ ha; Smith et al. 2001). In GSMNP, oak-hickory forest covers $\sim 64600$ ha (31\% of the Park's total forest cover; Madden et al. 2004). The geographic range of $C$. florida encompasses most of the area covered by oak-hickory forest in eastern North America. Whether other forests in the East have experienced changes in $\mathrm{Ca}$ cycling due to dogwood anthracnose is unknown. Differences in understory species composition and variations in parent material fertility could influence $\mathrm{Ca}$ cycling. For example, sites where hardwood species such as $A$. saccharum have replaced $C$. florida in the understory will exhibit less change in intra-stand $\mathrm{Ca}$ cycling than southern Appalachian sites where $C$. florida was replaced by $T$. canadensis.
The loss of $\mathrm{Ca}$ from the forest floor and surface soil of eastern forests may have cascading effects on a range of biota. Studies have shown that the density of snails and millipedes is strongly correlated with the local availability of Ca (Gist and Crossley 1975, Hotopp 2002). Reductions in forest-floor $\mathrm{Ca}$ caused by acid deposition results in lower densities of snails, which in turn causes decreased reproduction by passerine birds that depend upon $\mathrm{Ca}$ in snail shells for eggshell production (Graveland et al. 1994). Within the southern Appalachians, GSMNP serves as a substantial population source for Wood Thrush and other songbirds (Wilcove 1988, Simons et al. 2000). The loss of $\mathrm{Ca}$ from the forest floors of hardwood stands, combined with impacts of acid deposition at higher elevations (Hames et al. 2002), could have long-term negative impacts on songbird populations throughout the region.

Because of the ecological importance of $C$. florida, active management should be used to prevent the loss of this species from eastern forests. While techniques exist for controlling anthracnose in horticultural settings, techniques for controlling the disease across large areas of continuous forests have proved elusive. Britton et al. (1994) found clearcut harvesting reduced the severity of dogwood anthracnose in post-harvest stands. However, creating large clearcuts to benefit a single understory species would be inappropriate and impractical for most ecosystem management plans and is not a management option on parkland such as GSMNP. Recent work in GSMNP has shown that past burning has reduced the impacts of dogwood anthracnose by creating more open stand conditions that reduce the virulence of the fungus (Holzmueller 2006), suggesting that prescribed fire may offer the best option to prevent the loss of $C$. florida from oak-hickory and oak-pine forests. Based upon our research, preventing the loss of $C$. florida may be important to maintaining the long-term health of eastern forests.

\section{ACKNOWLEDGMENTS}

We thank Mary Breslin, Bob Dellinger, Cathy Hardin, Jon Harrod, Eric Holzmueller, Steve Gagnon, P. J. Jones, Heather MacCulloch, Sarah Merritt, Daniel Noon, Craig Ramsey, Art vonLehe, Mark Whited, and Leslie Witter for their assistance with fieldwork, data entry, and sample preparation. We also thank Michael Kunze for reformatting the 1977-1979 data set and Keith Langdon, Becky Nichols, Brian Kloeppel, and two anonymous reviewers for their helpful comments on earlier versions of the manuscript.

\section{Literature Cited}

Blair, J. M. 1988. Nutrient release from decomposing foliar litter of three tree species with special reference to calcium, magnesium, and potassium dynamics. Plant and Soil 110:4955.

Boerner, R. E. J., and J. A. Kost. 1986. Biomass equations for flowering dogwood, Cornus florida L. Castanea 51:153-155.

Brady, N. C. 1990. The nature and properties of soils. Tenth edition. Macmillan, New York, New York, USA.

Britton, K. 1994. Dogwood anthracnose. Pages 17-20 in C. Ferguson and P. Bowman, editors. Threats to forest health in 
the southern Appalachians. Southern Appalachian Man and the Biosphere Cooperative, Gatlinburg, Tennessee, USA.

Britton, K. O., P. Berrang, and E. Mavity. 1996. Effects of pretreatment with simulated acid rain on the severity of dogwood anthracnose. Plant Disease 80:646-649.

Britton, K. O., W. D. Pepper, D. L. Loftis, and D. O. Chellemi. 1994. Effect of timber harvest practices on populations of Cornus florida and severity of dogwood anthracnose in western North Carolina. Plant Disease 78:398-402.

Cronan, C. S., and C. L. Schofield. 1990. Relationships between aqueous aluminum and acid deposition in forested watersheds of North America and northern Europe. Environmental Science and Technology 24:1100-1105.

Crow, T. R. 1978. Biomass and production in three contiguous forests in northern Wisconsin. Ecology 59:265-273.

Daughtrey, M. L., and C. R. Hibben. 1994. Dogwood anthracnose: a new disease threatens two native Cornus species. Annual Review of Phytopathology 32:61-73.

Day, F. P., and C. D. Monk. 1977. Seasonal nutrient dynamics in the vegetation of a southern Appalachian watershed. American Journal of Botany 64:1126-1139.

Dijkstra, F. A., and M. M. Smits. 2002. Tree species effects on calcium cycling; the role of calcium uptake in deep soils. Ecosystems 5:385-398.

Driscoll, C. T., G. B. Lawrence, A. J. Bulger, T. J. Butler, C. S. Cronan, C. Eagar, K. F. Lambert, G. E. Likens, J. L. Stoddard, and K. C. Weathers. 2001. Acid deposition in the northeastern United States: sources and inputs, ecosystem effects, and management strategies. BioScience 51:180-198.

Federer, C. A., J. W. Hornbeck, L. M. Tritton, W. C. Martin, R. S. Pierce, and C. T. Smith. 1989. Long-term depletion of calcium and other nutrients in eastern U.S. forests. Environmental Management 13:593-601.

Finzi, A. C., C. D. Canham, and N. Van Breeman. 1998. Canopy tree-soil interactions within temperate forests: species effects on $\mathrm{pH}$ and cations. Ecological Applications $8: 447-454$.

Gist, C. S., and D. A. Crossley. 1975. The litter arthropod community of a southern Appalachian hardwood forest: numbers, biomass, and mineral element content. American Midland Naturalist 93:107-122.

Graveland, J. R. 1996. Avian eggshell formation in calcium-rich and calcium-poor habitats; importance of snail shells and anthropogenic calcium sources. Canadian Journal of Zoology 74:1035-1044.

Graveland, J. R., R. van der Wal, J. H. van Balen, and A. J. van Noordwijk. 1994. Poor reproduction in forest passerines from decline of snail abundance on acidified soils. Nature 368:446-448.

Hames, R. S., K. V. Rosenberg, J. D. Lowe, S. E. Baker, and A. A. Dhondt. 2002. Adverse effects of acid rain on the distribution of the wood thrush Hylocichla mustelina in North America. Proceedings of the National Academy of Sciences (USA) 99:11235-11240.

Hiers, J. K., and J. P. Evans. 1997. Effects of anthracnose on dogwood mortality and forest composition of the Cumberland Plateau (U.S.A.). Conservation Biology 11:1430-1435.

Holzmueller, E. J. 2006. Ecology of flowering dogwood (Cornus florida L.) in response to anthracnose and fire in Great Smoky Mountains National Park, USA. Dissertation. University of Florida, Gainesville, Florida, USA.

Holzmueller, E. J., S. Jose, and M. A. Jenkins. In press. Influence of calcium, potassium, and magnesium on Cornus florida L. density and resistance to dogwood anthracnose. Plant and Soil.

Holzmueller, E. J., S. Jose, M. A. Jenkins, A. E. Camp, and A. J. Long. 2006. Dogwood anthracnose: What is known and what can be done? Journal of Forestry 104:21-26.

Hotopp, K. P. 2002. Land snails and soil calcium in central Appalachian mountain forest. Southeastern Naturalist 1:2744.
Huntington, T. G. 2000. The potential for calcium depletion in forest ecosystems of the southern United States: review and analysis. Global Biogeochemical Cycles 14:623-638.

Huntington, T. G., R. P. Hooper, C. E. Johnson, B. T. Aulenbach, R. Cappellato, and A. E. Blum. 2000. Calcium depletion in a southeastern United States forest ecosystem. Soil Science Society of America Journal 64:1845-1848.

Jenkins, M. A., and G. R. Parker. 1998. Composition and diversity of woody vegetation in silvicultural openings of southern Indiana forests. Forest Ecology and Management 109:57-74.

Jenkins, M. A., and P. S. White. 2002. Cornus florida mortality and understory composition changes in western Great Smoky Mountains National Park. Journal of the Torrey Botanical Society 129:194-206.

Johnson, A. H., S. B. Anderson, and T. G. Siccama. 1994. Acid rain and soils of the Adirondacks. I. Changes in $\mathrm{pH}$ and soil calcium. Canadian Journal of Forest Research 24:193-198.

Johnson, D. W., G. S. Henderson, and D. E. Todd. 1988. Changes in nutrient distribution on forests and soils of Walker Branch Watershed over an eleven-year period. Biogeochemistry 5:275-293.

Johnson, D. W., and S. E. Lindberg. 1992. Atmospheric deposition and forest nutrient cycling: a synthesis of the Integrated Forest Study. Springer-Verlag, New York, New York, USA.

Johnson, D. W., and D. E. Todd. 1990. Nutrient cycling in forests of Walker Branch Watershed, Tennessee: roles of uptake and leaching in causing soil changes. Journal of Environmental Quality 19:97-104.

Jones, J. B., Jr. 1998. Plant nutrition manual. CRC Press, New York, New York, USA.

Jönsson, U., U. Rosengren, G. Thelin, and B. Nihlgård. 2003. Acidification-induced chemical changes in coniferous forest soils in southern Sweden: 1988-1999. Environmental Pollution 123:75-83.

Knoepp, J. D., B. C. Reynolds, D. C. Crossley, and W. T. Swank. 2005. Long-term changes in forest floor processes in southern Appalachian forests. Forest Ecology and Management 220:300-312.

Kobe, R. K. 1996. Intraspecific variation in sapling mortality and growth predicts geographic variation in forest composition. Ecological Monographs 66:181-201.

Kost, J. A., and R. E. J. Boerner. 1985. Foliar nutrient dynamics and nutrient use efficiency in Cornus florida. Oecologia 66:602-606.

Lawrence, G. B., M. B. David, G. M Lovett, P. S. Murdoch, D. A. Burns, J. L. Stoddard, B. P. Baldigo, J. H. Porter, and A. W. Thompson. 1999. Soil calcium status and the response of stream chemistry to changing acidic deposition rates in the Catskill Mountains of New York. Ecological Applications 9: 1059-1072.

Lawrence, G. B., M. B. David, and W. C. Shortle. 1995. A new mechanism for calcium loss in forest floor soils. Nature 378: $162-164$.

Likens, G. E., C. T. Driscoll, and D. C. Buso. 1996. Long-term effects of acid rain: responses and recovery of a forest ecosystem. Science 272:244-246.

Long, J. N., and J. Turner. 1975. Aboveground biomass of understorey and overstorey in an age sequence of four Douglas-fir stands. Journal of Applied Ecology 2:79-188.

Madden, M., R. Welch, T. Jordan, and P. Jackson. 2004. Digital vegetation maps for Great Smoky Mountains National Park: final report. Center for Remote Sensing and Mapping Science, Department of Geography, University of Georgia, Athens, Georgia, USA.

Martin, J. G., B. D. Kloeppel, T. L. Schaefer, D. L. Kimbler, and S. G. McNulty. 1998. Aboveground biomass and nitrogen allocation of ten deciduous southern Appalachian tree species. Canadian Journal of Forest Research 28:16481659 . 
Matzner, E., and D. Murach. 1995. Soil changes induced by air pollutant deposition and their implication for forests in central Europe. Water, Air, and Soil Pollution 85:63-76.

McLaughlin, S. B., and R. Wimmer. 1999. Tansley review number 104: calcium physiology and terrestrial ecosystem processes. New Phytologist 142:373-417.

McLemore, B. F. 1990. Cornus florida L.-Flowering dogwood. Pages 278-283 in R. M. Burns and B. H. Honkala, editors. Silvics of North America. Volume 2. Hardwoods. Agriculture Handbook 654. USDA Forest Service, Washington, D.C., USA.

Mengel, K., E. A. Kirkby, H. Kosegarten, and T. Appel. 2001. Principles of plant nutrition. Fifth edition. Kluwer Academic Publishers, Dordrecht, The Netherlands.

Neter, J., M. H. Kutner, C. J. Nachtsheim, and W. Wasserman. 1996. Applied linear statistical models. Fourth edition. Richard D. Irwin, Homewood, Illinois, USA.

NPSpecies-The National Park Service Biodiversity Database. 2006. Secure online version. 〈http://science.nature.nps.gov/ npspecies/>

Oliver, C. D., and B. C. Larson. 1996. Forest stand dynamics, update edition. John Wiley and Sons, New York, New York, USA.

Pallardy, S. G., T. A. Nigh, and H. E. Garrett. 1988. Changes in forest composition in central Missouri: 1968-1982. American Midland Naturalist 120:380-390.

Potter, C. S., H. L. Ragsdale, and C. W. Berish. 1987. Resorption of foliar nutrients in a regenerating southern Appalachian forest. Oecologia 73:268-271.

Pritchett, W. L., and R. F. Fisher. 1987. Properties and management of forest soils. Second edition. John Wiley and Sons, New York, New York, USA.

Pyle, C. 1988. The type and extent of anthropogenic vegetation disturbance in the Great Smoky Mountains before National Park Service acquisition. Castanea 53:183-196.

Reich, P. B., D. S. Ellsworth, M. B. Walters, J. M. Vose, C. Gresham, J. C. Volin, and W. D. Bowman. 1999. Generality of leaf trait relationships: a test across six biomes. Ecology 80:1955-1969.

Rutkowski, D. R., and R. Stottlemyer. 1993. Composition, biomass, and nutrient distribution in mature northern hardwood and boreal forest stands, Michigan. American Midland Naturalist 130:13-30.

Santa Regina, I., S. Leonardi, and M. Rapp. 2001. Foliar nutrient dynamics and nutrient-use efficiency in Castanea sativa coppice stands of southern Europe. Forestry 74:1-10.

Simons, T. R., G. L. Farnsworth, and S. A. Shriner. 2000. Evaluating Great Smoky Mountains National Park as a population source for wood thrush. Conservation Biology 14:1133-1144.

Smith, W. B., J. S. Vissage, D. R. Darr, and R. M. Sheffield. 2001. Forest resources of the United States, 1997. General
Technical Report NC-219. USDA Forest Service, North Central Research Station, Saint Paul, Minnesota, USA.

Soltanpour, P. N., G. W. Johnson, S. M. Workman, J. B. Jones, and R. O. Miller. 1996. Inductively coupled plasma emission spectometry and inductively coupled plasma-mass spectroscopy. Pages 91-140 in D. L. Sparks, editor. Methods of soil analysis. Part 3. Chemical methods. Soil Science Society of America, Madison, Wisconsin, USA.

Son, Y., I. H. Park, M. J. Yi, H. O. Jun, D. Y. Kim, R. H. Kim, and J. O. Hwang. 2004. Biomass production and nutrient distribution of a natural oak forest in central Korea. Ecological Research 19:21-28.

Suarez, D. L. 1996. Beryllium, magnesium, calcium, strontium, and barium. Pages 575-602 in D. L. Sparks, editor. Methods of soil analysis. Part 3. Chemical methods. Soil Science Society of America. Madison, Wisconsin, USA.

Sumner, M. E., and W. P. Miller. 1996. Cation exchange capacity and exchange coefficients. Pages 1201-1230 in D. L. Sparks, editor. Methods of soil analysis. Part 3. Chemical methods. Soil Science Society of America, Madison, Wisconsin, USA.

Taylor, G. 2002. Hemlock resources at Great Smoky Mountains National Park. Pages 34-35 in B. Onken, R. Reardon, and J. Lashomb, editors. Proceedings of the hemlock woolly adelgid in the eastern United States symposium (East Brunswick, New Jersey, USA). New Jersey Agriculture Experiment Station, Rutgers, New Brunswick, New Jersey, USA.

Thomas, W. A. 1969. Accumulation and cycling of calcium by dogwood trees. Ecological Monographs 39:101-120.

Van Den Driessche, R. 1974. Prediction of mineral nutrient status of trees by foliar analysis. Botanical Review 40:347394.

White, P. S., and R. T. Busing. 1993. LTERM: Long-term monitoring and research in Great Smoky Mountains National Park, vegetation monitoring and an assessment of past studies. Technical Report NPS/sergrsm/nrtr-93/10. National Park Service, Southeast Region, Atlanta, Georgia, USA.

White, R. D., K. D. Patterson, A. Weakley, C. J. Ulrey, and J. Drake. 2003. Vegetation classification of Great Smoky Mountains National Park. Unpublished report submitted to BRD-NPS [USGS Biological Resources Division-National Park Service] Vegetation Mapping Program by NatureServe, Durham, North Carolina, USA.

Wilcove, D. S. 1988. Changes in the avifauna of the Great Smoky Mountains: 1947-1983. Wilson Bulletin 100:256-271.

Wyckoff, P. H., and J. S. Clark. 2002. The relationship between growth and mortality for seven co-occurring tree species in the southern Appalachian Mountains. Journal of Ecology 90: 604-615.

\section{APPENDIX A}

Allometric equations used to determine foliar biomass of 35 woody species across five forest types. (Ecological Archives A017032-A1)

\section{APPENDIX B}

Tables reporting changes in foliar biomass and calcium content of selected understory species and summed totals of all understory species across five forest types. (Ecological Archives A017-032-A2) 